\title{
Lyme-nevroborreliose ved uspesifikke nevrologiske symptomer
}

\begin{abstract}
BAKGRUNN For å stille diagnosen Lyme-nevroborreliose kreves undersøkelse av spinalvæsken. Vi undersøkte hvilke symptomer pasientene fra et høyendemisk område som ble henvist for utredning av tilstanden hadde, og hvorvidt de fikk bekreftet eller avkreftet diagnosen Lyme-nevroborreliose ved undersøkelse av spinalvæsken.
\end{abstract}

METODE Vi gjennomgikk samtlige journaler til pasienter som ble utredet med spinalpunksjon ved Sørlandet sykehus i Arendal i perioden 1.1. 2013-31.12. 2013.

RESULTATER Totalt ble 140 pasienter henvist med mistanke om Lyme-nevroborreliose. 110 pasienter hadde uspesifikke nevrologiske symptomer (f.eks. tretthet, svimmelhet og hodepine) og av disse var det kun én som fikk diagnosen mulig Lyme-nevroborreliose. 30 pasienter hadde typiske symptomer på tilstanden (som radikulitt eller perifer facialisparese). Seks av disse fikk diagnosen sikker Lyme-nevroborreliose, mens én fikk diagnosen mulig Lymenevroborreliose. Ingen av dem som ble diagnostisert med Lyme-nevroborreliose hadde hatt symptomer med varighet over seks måneder.

FORTOLKNING Ved fravær av typiske symptomer på Lyme-nevroborreliose er sannsynligheten for tilstanden lav, selv ved funn av antiborreliaantistoff i serum og særlig om symptomene er av lang varighet.

Borreliose er en vektorbåren zoonose som kan forårsakes av smitte med spirocheten Borrelia burgdorferi etter flåttbitt (1). Tidlig lokalisert sykdom inkluderer erythema migrans, og omkring halvparten vil ha allmennsymptomer som feber, myalgi, lymfadenopati og hodepine (2).

Lyme-nevroborreliose er den vanligste disseminerte formen for borreliose i Europa. Tilstanden er rapportert hos 3-12\% av dem med ubehandlet tidlig lokalisert sykdom, vanligvis fire til åtte uker etter flåttbitt, men både tidligere og senere debut kan forekomme (3-7). Det vanligste kliniske bilde ved Lyme-nevroborreliose er Bannwarths syndrom, som består av perifer facialisparese eller øyemuskelparese, radikulitt med symptomer i form av radierende smerter, følelsesendringer og/eller lammelser samt funn av lymfocytter i spinalvæsken $(7,8)$. Hos barn er det vanlig med facialisparese og lavgradige meningittsymptomer uten radikulitt (9). I sjeldnere tilfeller av Lyme-nevroborreliose kan det oppstå perifere nevropatier, kognitiv påvirkning, cerebellær ataksi, encefalitt og myelitt $(1,7)$.

I Norge benytter man europeiske retningslinjer for diagnostikk av Lyme-nevroborreliose. De krever nevrologiske symptomer forenlig med sykdommen og spinalpunksjon med funn av pleocytose og positiv antistoffindeks som tegn på intratekal antiborreliaantistoffproduksjon (ramme 1) (10). Hos $10-30 \%$ av dem med symptomvarighet på under seks uker finner man ikke borreliaantistoffer i spinalvæsken eller i serum, noe som gjør diagnostikken i tidlig fase utfordrende (11).
Etter gjennomgått og behandlet Lymenevroborreliose kan 28-50\% utvikle postLyme-sykdomssyndrom (PLSD), som innebærer utmattelse (fatigue), nevropsykologiske plager og dårligere livskvalitet $(12,13)$. Diagnostiske kriterier for denne tilstanden er blitt foreslått, men det råder fremdeles usikkerhet og kontroverser rundt årsak, diagnostikk og klinisk betydning (14-16).

I 2015 ble det registrert 425 tilfeller av disseminert borreliose, nevroborreliose, Lymekarditt, Lyme-artritt m.m. i Norge (17). Langs kysten av Agderfylkene kan opptil 31,1 \% av flåtten være bærere av ulike Borrelia-arter, og området betraktes som høyendemisk (18).

Ved Sørlandet sykehus har man registrert en økning av henvisninger der det er spørsmål om Lyme-nevroborreliose de siste årene. Vi ønsket å undersøke hvilke symptomer disse pasientene hadde, hvor lenge de hadde hatt symptomene, hvilke spinalvæskefunn som ble gjort og endelig diagnose.

\section{Materiale og metode \\ Pasienter}

Journalene til alle polikliniske og innlagte pasienter som ble spinalpunktert ved Nevrologisk avdeling, Sørlandet sykehus i Arendal i tidsrommet 1.1. 2013-31.12. 2013 ble gjennomgått. Fra henvisningsskriv, polikliniske notater, laboratoriesvar og epikriser ble det registrert henvisningsårsak, anamnese på flåttbitt, symptomer, symptomvarighet, funn i spinalvæsken, endelig diagnose, behandling og komplikasjoner.

Pasientene ble sortert i to grupper. Den ene

\author{
Erlend Roaldsnes \\ erlend.roaldsnes@gmail.com \\ Oslo universitetssykehus, Ullevål \\ og \\ Det medisinske fakultet \\ Universitetet i Oslo

\section{Randi Eikeland} \\ Nevrologisk avdeling \\ Sørlandet sykehus, Arendal \\ og \\ Nasjonal kompetansetjeneste \\ for flåttbårne sykdommer \\ Dag Berild \\ Institutt for klinisk medisin \\ Universitetet i Oslo \\ og \\ Infeksjonsavdelingen \\ Oslo universitetssykehus \\ > Se lederartikkel side 86
}

Engelsk oversettelse på www.tidsskriftet.no

\section{HOVEDBUDSKAP}

Det var lav risiko for Lyme-nevroborreliose ved langvarige uspesifikke nevrologiske symptomer, også der det var funn av antiborreliaantistoffer i serum

Lyme-nevroborreliose bør mistenkes hos pasienter med smertefull radikulitt som forverres om natten, spesielt ledsaget av nummenhet som følger et eller flere dermatomer og perifer facialisparese

Pasienter med symptomer på Lyme-nevroborreliose bør utredes med spinalpunksjon 


\section{RAMME 1}

Europeiske retningslinjer for diagnostikk av Lyme-nevroborreliose (10)

\section{Kriterier}

Nevrologiske symptomer forenlig med Lyme-nevroborreliose uten annen opplagt årsak

Pleocytose i spinalvæske

Positiv antistoffindeks som tegn på intratekal antiborreliaantistoffproduksjon

\section{Tolkning}

3 av 3 kriterier: Sikker Lyme-nevroborreliose

2 av 3 kriterier: Mulig Lyme-nevroborreliose 1 av 3 kriterier: Ingen Lyme-nevroborreliose

gruppen presenterte symptomer typiske for Lyme-borreliose som inkluderte radikulitt, perifer facialisparese eller andre sentralnervøse symptomer. Den andre gruppen besto av pasienter som presenterte uspesifikke symptomer som tretthet/fatigue, svimmelhet, konsentrasjonsvansker, myalgier, uspesifikke parestesier og tensjonslignende hodepine. Inndelingen ble gjort av førsteforfatter.

\section{Datamateriale}

I den oppgitte perioden ble det utført totalt 240 spinalpunksjoner, der $140(58 \%)$ var i forbindelse med utredning for mulig Lymenevroborreliose. Disse 140 inkluderer ikke pasienter der spinalvæsken ble undersøkt for borreliaantistoffer som ledd i utredning av annen sykdom, som demens, multippel sklerose og kronisk utmattelsessyndrom (CFS/ ME). Til sammen ble 100 pasienter ekskludert.

Det var utført analyser for borreliaantistoffer i serum og samtlige spinalvæskeprøver var sendt til analyse for borreliaantistoffer og antistoffindeks for påvisning av intratekal antistoffproduksjon samt undersøkelse av celler og protein i spinalvæsken. Alle analysene var utført ved Avdeling for medisinsk mikrobiologi ved Sørlandet sykehus, som er referanselaboratorium for borreliaanalyser i Norge.

For serum og spinalvæske benyttes Siemens Enzygnost Lyme link VlsE/IgG og Siemens Enzygnost Borreliosis IgM. IgGantistoffindeks beregnes i henhold til Riebers metode (11). Borrelia-IgG i serum angis i prosent av grenseverdien ( $\%$ av cutoff), der grenseverdien er laveste mulige positive verdi. Denne verdien blir beregnet for hvert enkelt oppsett og varierer. Ved lave verdier, f.eks. $200 \%$ av grenseverdien, er det større fare for at påviste antistoff ikke er spesifikt rettet mot Borrelia enn ved resultater som ligger høyere, for eksempel $800 \%$ av grenseverdien (19). Data ble analysert i IBM SPSS 22.0.

\section{Etikk}

Studien er lagt frem for regional etisk komité og ble vurdert som ikke meldepliktig. Den ble godkjent av forskningsleder ved Sørlandet sykehus.

\section{Resultater}

Av de 140 pasientene fikk seks diagnosen sikker Lyme-nevroborreliose og to diagnosen mulig Lyme-nevroborreliose. Gjennomsnittsalderen i denne gruppen var 48 år, og det var $53 \%$ kvinner. Det var ingen signifikant forskjell i alder og kjønn i henhold til symptomer og endelig diagnose.

$\mathrm{Av}$ de 30 pasientene i gruppen med typiske symptomer var det seks som hadde sikker Lyme-nevroborreliose og én som hadde mulig Lyme-nevroborreliose. Av de 110 pasientene med uspesifikke nevrologiske symptomer var det én pasient der tilstanden ble tolket som mulig Lyme-nevroborreliose (tab 1).

Av de pasientene som ikke fikk diagnosen hadde $52 \%$ myalgier, $43 \%$ tretthet/fatigue og $42 \%$ uspesifikke parestesier. $8 \%$ hadde hatt flåttbitt i løpet av de siste tre måneder og $5 \%$ hadde hatt utslett suspekt på erythema migrans. I denne gruppen var det $45 \%$ som hadde hatt symptomer i under tre måneder og $30 \%$ som hadde hatt symptomer i over 12 måneder ( $\operatorname{tab} 2)$. Av de åtte som fikk diagnosen sikker eller mulig Lyme-nevroborreliose, hadde $63 \%$ perifer facialisparese og $50 \%$ radikulitt og parestesier med utbredelse i dermatom. Ingen oppga å ha hatt erythema migrans. To av de åtte hadde anamnese på flåttbitt i løpet av de siste tre månedene.

$24 \%$ av pasientene som ble henvist til utredning for Lyme-nevroborreliose på bakgrunn av nyoppstått perifer facialisparese fikk diagnosen sikker eller mulig sykdom Alle de seks som fikk diagnosen sikker Lyme-nevroborreliose, hadde positive borrelia-IgG-antistoffer i serum, med en verdi på over $650 \%$ av grenseverdien.

\section{Diskusjon}

I vår undersøkelse fant vi at $79 \%$ av dem som ble henvist til utredning med spinalpunksjon for Lyme-nevroborreliose, ikke hadde vanlige symptomer på tilstanden - de ble henvist på grunn av uspesifikke nevrologiske symptomer som langvarig tretthet, uspesifikke parestesier, konsentrasjonsproblemer og myalgier. Denne pasientgruppen hadde liten sannsynlighet for å få diagnosen.

Mange av dem som fikk diagnosene sikker eller mulig Lyme-nevroborreliose, hadde hatt symptomer i under tre måneder, og ingen hadde hatt symptomer i mer enn seks måneder. Dette kan indikere at lengre tid med uspesifikke plager gjør diagnosen Lyme-nevroborreliose mindre sannsynlig. Symptomene ved tilstanden er oftest av en slik art at pasientene oppsøker lege relativt raskt og utredning blir startet. Av dem som ikke hadde typiske symptomer, var det en stor andel som hadde hatt plager i over ett år. Ingen av disse fikk diagnosen.

Internasjonalt blir det diskutert om det er nødvendig med spinalpunksjon for å kunne stille diagnosen Lyme-nevroborreliose. I USA er dette ikke påkrevd, men i Europa krever man funn i spinalvæsken $(7,10,20$, 21). Av enkelte leger og pasienter blir det argumentert for at Lyme-nevroborreliose kan diagnostiseres ut fra symptomer alene, også uspesifikke symptomer som tretthet, myalgier og hodepine, og ved bruk av ikkevaliderte tester $(15,22)$. Uspesifikke symptomer er vanlig i normalbefolkningen, og manglende dokumentasjon på at dette kan være forårsaket av Lyme-nevroborreliose, har gjort at disse diagnostiske kriteriene ikke er anerkjent av de store fagmiljøene internasjonalt $(8,14-16,23,24)$. Søkelys på mulig

Tabell 1 Antall personer som fikk diagnosen Lyme-nevroborreliose av pasienter med eller uten typiske symptomer hos dem som var henvist for utredning for mulig Lyme-nevroborreliose og spinalpunktert ved Nevrologisk avdeling, Sørlandet sykehus, Arendal, i perioden 1.1. 2013-31.12. 2013

\begin{tabular}{|c|c|c|c|}
\hline $\begin{array}{l}\text { Ingen } \\
\text { Lyme-nevroborreliose }\end{array}$ & $\begin{array}{c}\text { Mulig } \\
\text { Lyme-nevroborreliose }\end{array}$ & $\begin{array}{c}\text { Sikker } \\
\text { Lyme-nevroborreliose }\end{array}$ & Totalt \\
\hline 109 & 1 & 0 & 110 \\
\hline 23 & 1 & 6 & 30 \\
\hline 132 & 2 & 6 & 140 \\
\hline
\end{tabular}


Tabell 2 Antall med ulike symptomer og symptomvarighet ved sikker eller mulig Lyme-nevroborreliose og ingen Lyme-nevroborreliose hos dem som var henvist for utredning for mulig Lymenevroborreliose og spinalpunktert ved Nevrologisk avdeling. Sørlandet sykehus, Arendal, i perioden 1.1. 2013-31.12. 2013

$$
\begin{array}{cc}
\text { Sikker eller mulig } & \text { Ingen } \\
\text { Lyme-nevroborreliose } & \text { Lyme-nevroborreliose } \\
(n=8) & (n=132)
\end{array}
$$

\section{Symptomer}

\begin{tabular}{lll} 
Hjernenerveutfall & 5 & 16 \\
Radikulitt & 4 & 11 \\
Parestesier & 4 & 55 \\
Myalgier & 3 & 69 \\
Tensjonslignende hodepine & 3 & 45 \\
Tretthet & 1 & 57 \\
Svimmelhet & 1 & 39 \\
Meningittsymptomer & 0 & 1 \\
Konsentrasjonsproblemer & 0 & 28 \\
Flåttbitt siste 3 måneder & 2 & 8 \\
Erythema migrans & 0 & 6 \\
Symptomvarighet & & 36 \\
$<1$ md. & 4 & 23 \\
1-3 md. & 2 & 10 \\
$3-6$ md. & 1 & 15 \\
$6-12$ md. & 0 & 40 \\
$>12$ md. & 0 & 8 \\
Ukjent & 1 & \\
\hline
\end{tabular}

underdiagnostikk av Lyme-nevroborreliose hos personer med medisinsk uforklarte plager kan ha ført til den økte pågangen for utredning med spinalpunksjon som vi har sett i de senere år.

I vårt materiale fant vi at alle med sikker Lyme-nevroborreliose hadde relativt høye titere av borrelia-IgG-antistoffer i serum. $27 \%$ av dem uten diagnosen hadde tilsvarende verdier. I Sogn og Fjordane er det funnet at $10 \%$ av friske blodgivere er borreliaIgG-seropositive - uten at dette var assosiert med helseplager $(24,25)$. I Vest-Agder har $18 \%$ av befolkningen antistoffer i serum (26). Etter eksponering for Borrelia kan man være seropositiv i flere år, både for IgM og $\operatorname{IgG}$ (27). Det kan virke som om flere av dem med uspesifikke nevrologiske symptomer fikk påvist borreliaantistoffer hos primærlege og deretter ble henvist til utredning for Lyme-nevroborreliose. Funn av antiborreliaantistoffer i serum betyr ikke at årsaken til pasientens helseplager er Lyme-nevroborreliose, men et slikt funn kan være en støtte i diagnostikken hos dem som har symptomer på tilstanden (24).

Perifer facialisparese var til stede hos $63 \%$ av pasientene med mulig eller sikker Lyme-nevroborreliose, og $24 \%$ av dem som ble utredet for perifer facialisparese fikk enten diagnosen mulig eller sikker Lymenevroborreliose. Ingen av de åtte med sikker eller mulig Lyme-nevroborreliose hadde hatt utslett suspekt på erythema migrans, og bare to husket å ha blitt bitt av flått de siste tre månedene. Det er kjent at om lag halvparten av pasienter med Lyme-nevroborreliose ikke husker at de har hatt flåttbitt eller erythema migrans $(7,28)$.

Ved nyoppstått perifer fascialisparese er altså Lyme-nevroborreliose en viktig differensialdiagnose, uavhengig av om pasienten kan huske å ha hatt flåttbitt eller erythema migrans. Ved Sørlandet sykehus har man innført spinalpunksjon av alle med perifer facialisparese, og våre resultater støtter denne praksisen $\mathrm{i}$ et høyendemisk område for Borrelia. Ingen som fikk diagnosen mulig eller sikker Lyme-nevroborreliose hadde symptomer på meningitt (hodepine med samtidig lys- og lydskyhet, kvalme eller oppkast). Symptomene ved borreliameningitt kan være uttalte, men ligner ofte symptomer som man også ser ved viral meningitt - varierende grad av hodepine og svingende feber, men uten andre tegn til meningitt (29).

En svakhet med vårt datamateriale er at det er basert på journalgjennomgang og ikke på direkte samtale og undersøkelse av pasienten. Datamaterialet er relativt lite - med kun seks pasienter med sikker Lyme-nevroborreliose. De fleste journalene og henvisningene ga et godt bilde av pasientens symptomer og sykehistorie, men usikkerhet rundt anamnesen og kliniske funn har vi ikke hatt mulighet til å etterprøve. Vi har antatt at dersom et symptom ikke er beskrevet $i$ henvisning eller journalnotater, så har ikke pasienten hatt dette symptomet - noe som ikke kan utelukkes med sikkerhet. Vedkommende som registrerte symptomer var ikke formelt blindet for funnene i spinalvæsken.

Vi takker Cathrine Brunborg ved Oslo Centre for Biostatistics and Epidemiology for statistisk rådgivning og Sølvi Noraas og Guro Helen Furset Jensen ved Avdeling for medisinsk mikrobiologi ved Sørlandet sykehus for hjelp med beskrivelse av laboratoriediagnostikk av Lyme-nevroborreliose.

\section{Erlend Roaldsnes (f. 1987)}

er turnuslege.

Forfatter har fylt ut ICMJE-skjemaet og oppgir ingen interessekonflikter.

\section{Randi Eikeland (f. 1966)}

er dr.med., overlege og leder for Nasjonalt kompetansesenter for flåttbårne sykdommer. Hun disputerte med avhandlingen European neuroborreliosis. Long-term follow-up.

Forfatter har fylt ut ICMJE-skjemaet og oppgir ingen interessekonflikter.

\section{Dag Berild (f. 1951)}

er professor, dr.med., spesialist i infeksjonssykdommer og overlege.

Forfatter har fylt ut ICMJE-skjemaet og oppgir ingen interessekonflikter.

\section{Litteratur}

1. Stanek G, Wormser GP, Gray J et al. Lyme borreliosis. Lancet 2012; 379: 461-73.

2. Nadelman RB, Nowakowski J, Forseter $\mathrm{G}$ et al. The clinical spectrum of early Lyme borreliosis in patients with culture-confirmed erythema migrans. Am J Med 1996; 100: 502-8. 
3. Stanek G, Strle F. Lyme disease: European perspective. Infect Dis Clin North Am 2008; 22: 327-39, vii. vii.

4. Bacon RM, Kugeler KJ, Mead PS. Surveillance for Lyme disease-United States, 1992-2006. MMWR Surveill Summ 2008; 57: 1-9.

5. Halperin JJ. Nervous system Lyme disease. Infect Dis Clin North Am 2015; 29: 241-53.

6. Hansen K, Lebech AM. The clinical and epidemiological profile of Lyme neuroborreliosis in Denmark 1985-1990. A prospective study of 187 patients with Borrelia burgdorferi specific intrathecal antibody production. Brain 1992; 115: 399-423.

7. Oschmann P, Dorndorf W. Hornig C et al. Stages and syndromes of neuroborreliosis. J Neurol 1998 245: $262-72$.

8. Ogrinc K, Lotrič-Furlan S, Maraspin V et al. Suspected early Lyme neuroborreliosis in patients with erythema migrans. Clin Infect Dis 2013; 57: 501-9.

9. Øymar K, Tveitnes D. Clinical characteristics of childhood Lyme neuroborreliosis in an endemic area of northern Europe. Scand J Infect Dis 2009; 41: 88-94.

10. Mygland A, Ljøstad U, Fingerle $V$ et al. EFNS guidelines on the diagnosis and management of European Lyme neuroborreliosis. Eur J Neurol 2010; 17: 8-16, e1-4.

11. Djukic M, Schmidt-Samoa C, Lange P et al. Cerebrospinal fluid findings in adults with acute Lyme neuroborreliosis. J Neurol 2012; 259: 630-6.

12. Eikeland R, Mygland A, Herlofson K et al. European neuroborreliosis: quality of life 30 months after treatment. Acta Neurol Scand 2011; 124: $349-54$
13. Dersch R, Sommer H, Rauer S et al. Prevalence and spectrum of residual symptoms in Lyme neuroborreliosis after pharmacological treatment: a systematic review. J Neurol 2016; 263: 17-24.

14. Wormser GP, Weitzner E, McKenna D et al. Longterm assessment of fatigue in patients with culture-confirmed Lyme disease. Am J Med 2015; 128: $181-4$

15. Feder HM Jr, Johnson BJ, O'Connell S et al. A critical appraisal of «chronic Lyme disease». N Engl J Med 2007: 357: 1422-30.

16. Wormser GP, Dattwyler RJ, Shapiro ED et al. The clinical assessment, treatment, and prevention of lyme disease, human granulocytic anaplasmosis, and babesiosis: clinical practice guidelines by the Infectious Diseases Society of America. Clin Infect Dis 2006; 43: 1089-134.

17. Ocampo JMF, Jore S, Vold I et al. Årsrapport. Flått og flåttbårne sykdommer i 2015. Oslo: Folkehelseinstituttet, 2016

18. Kjelland V, Stuen S, Skarpaas T et al. Prevalence and genotypes of Borrelia burgdorferi sensu lato infection in Ixodes ricinus ticks in southern Norway. Scand J Infect Dis 2010; 42: 579-85.

19. Grude N. Laboratoriediagnostikk ved borreliose. Strategirapport. Oslo: Folkehelseinstituttet, 2011.

20. Rupprecht TA, Pfister HW. What are the indications for lumbar puncture in patients with Lyme disease? Curr Probl Dermatol 2009; 37: 200-6.

21. Stanek G. Fingerle V. Hunfeld KP et al. Lyme borreliosis: clinical case definitions for diagnosis and management in Europe. Clin Microbiol Infect 2011 17: $69-79$.

22. Cameron D, Gaito A, Harris N et al. Evidence-based guidelines for the management of Lyme disease. Expert Rev Anti Infect Ther 2004; 2 (suppl): S1-13.

23. Ljøstad U, Mygland Å. Chronic Lyme; diagnostic and therapeutic challenges. Acta Neurol Scand Suppl 2013; 127: 38-47.

24. Hjetland R, Reiso H, Ihlebæk C et al. Subjective health complaints are not associated with tick bites or antibodies to Borrelia burgdorferi sensu lato in blood donors in western Norway: a crosssectional study. BMC Public Health 2015; 15: 657

25. Hjetland R, Nilsen RM, Grude N et al Seroprevalence of antibodies to Borrelia burgdorferi sensu lato in healthy adults from western Norway: risk factors and methodological aspects. APMIS 2014; 122: $1114-24$.

26. Mygland A, Skarpaas T, Ljøstad U. Chronic polyneuropathy and Lyme disease. Eur J Neurol 2006; 13: $1213-5$.

27. Kalish RA, McHugh G, Granquist J et al. Persistence of immunoglobulin $\mathrm{M}$ or immunoglobulin $\mathrm{G}$ antibody responses to Borrelia burgdorferi 10-20 years after active Lyme disease. Clin Infect Dis 2001; 33: 780-5.

28. Ljøstad U, Skogvoll E, Eikeland R et al. Oral doxycycline versus intravenous ceftriaxone for European Lyme neuroborreliosis: a multicentre, noninferiority, double-blind, randomised trial. Lancet Neurol 2008; 7: 690-5.

29. Stanek G, Strle F. Lyme borreliosis. Lancet 2003; 362: 1639-47.

Mottatt 20.10. 2015, første revisjon innsendt 9.3. 2016, godkjent 25.10. 2016. Redaktør: Tor Rosness. 